\title{
KlimaSeniorinnen: lessons from the Swiss senior women's case for future climate litigation
}

\author{
Cordelia Christiane Bähr* \\ bähr ettwein Attorneys-at-Law, Zurich, Switzerland \\ Ursula Brunner \\ ettlersuter Attorneys-at-Law, Zurich, Switzerland
}

\begin{abstract}
Kristin Casper
Greenpeace Canada, Litigation Counsel for the Global Climate Justice and Liability Campaign, Toronto, Canada
\end{abstract}

\author{
Sandra H Lustig \\ Freelance writer and translator, Hamburg, Germany
}

As older women are particularly vulnerable to climate change impacts, a group of senior women in Switzerland founded the association KlimaSeniorinnen Schweiz. (Senior Women for Climate Protection Switzerland) in order to fight for ambitious climate action by legally challenging the Swiss government's inadequate climate policies and mitigation measures. The KlimaSeniorinnen filed a legal request with the authorities, claiming that the Swiss authorities are failing to fulfil their duty to protect them as required by the Swiss Constitution and by the European Convention on Human Rights. This article provides a detailed analysis of the KlimaSeniorinnen case within the context of climate litigation worldwide. It argues that the case's human rights arguments, which are grounded in climate science, the United Nations Framework Convention on Climate Change (UNFCCC), the Paris Agreement, environmental principles and international law, are generally transferable to almost any country. Therefore, vulnerable individuals and groups can learn from the KlimaSeniorinnen litigation that there are strong legal grounds to bring human-rights-based climate lawsuits against governments and thus governments should expect more litigation if their climate actions or omissions contravene international law and violate constitutional principles.

Keywords: climate law, climate litigation, constitutional law, European Convention on Human Rights, gender, older persons, Paris Agreement, Switzerland

* The authors thank the members of KlimaSeniorinnen Schweiz for their determination, Greenpeace Switzerland for its support, Dr Harro van Asselt for suggesting the idea of writing about the KlimaSeniorinnen arguments that could travel, the anonymous reviewers and the JHRE editorial team for their valuable comments and suggestions. 


\section{INTRODUCTION}

People around the world are turning to the courts to ensure that ambitious action is taken to prevent dangerous climate change. ${ }^{1}$ Applying a strategy reminiscent of the civil rights era, the climate movement is mobilizing the law to demand protection of human rights. ${ }^{2}$ A global review of the status of climate change litigation explains that '[1]itigation has arguably never been a more important tool to push policymakers and market participants to develop and implement effective means of climate change mitigation and adaptation'. ${ }^{3}$ The case brought by KlimaSeniorinnen Schweiz (Senior Women for Climate Protection Switzerland) is one of many new climate cases involving human rights and constitutional law arguments. ${ }^{4}$

KlimaSeniorinnen Schweiz filed a legal request ${ }^{5}$ to four government authorities in Switzerland seeking a 'discontinuation of failures in climate protection' in order to ensure that greenhouse gas (GHG) emission reduction targets and measures are at a minimum in line with the Paris Agreement. ${ }^{6}$ The senior women allege violations of constitutional principles as well as of human rights enshrined in the Swiss constitution ${ }^{7}$ and the European Convention on Human Rights (ECHR). ${ }^{8}$ The authorities responded to the KlimaSeniorinnen request by declining to enter into the matter, arguing that since the request was brought in the public rather than in the applicants' interest, the matter should be handled by the Parliament. In May 2017 the senior women appealed to the Federal Administrative Court, which has not yet reached a verdict (section 4.1.4). This article presents the situation as at the end of April 2018.

1. Eg Urgenda Foundation $v$ The Netherlands (Ministry of Infrastructure and Environment) [2015] Verdict, The Hague District Court C/09/456689/HA ZA 13-1396 (2015) <http://www. urgenda.nl/documents/VerdictDistrictCourt-UrgendavStaat-24.06.2015.pdf> (hereinafter Urgenda; all references are to the English translation); Juliana v United States of America, Opinion and Order [2016] The United States District Court for the District of Oregon 6:15-cv-01517-TC US D Or, (2016) <https://www.ourchildrenstrust.org/s/Order-MTDAiken.pdf> (hereinafter Juliana); Asghar Leghari v Republic of Pakistan [2015] WP No 25501 Lahore High Court Green Bench [2015] Orders of 4 September and 14 September $2015<$ https://elaw.org/pk_Leghari> (hereinafter Leghari); Greenpeace Nordic Association et al. v Norway Ministry of Petroleum and Energy [2016] Oslo District Court <http://www.greenpeace.org/norway/Global/norway/Arktis/Dokumenter/ 2016/legal_writ_english_final_20161018.pdf> (hereinafter Greenpeace Nordic; all references are to the English translation). All websites mentioned in this article were accessed in December 2017. 2. NS Ghaleigh, "'Six Honest Serving-men": Climate Change Litigation as Legal Mobilization and the Utility of Typologies' (2010) 1 Climate Law 31, 34-5.

3. M Burger, J Gundlach, A Kreilhuber, L Ognibene, A Kariukia and A Gachie, The Status of Climate Change Litigation: A Global Review (UNEP and Sabin Center for Climate Change Law at Columbia University 2017), 8. <https://wedocs.unep.org/bitstream/handle/ 20.500.11822/20767/climate-change-litigation.pdf?sequence=1\&isAllowed=y $>$.

4. Ibid $14-20$.

5. Swiss Senior Women for Climate Protection v Swiss Federal Council et al., filed 25 October 2016, English translation, [3] <http://klimaseniorinnen.ch/wp-content/uploads/2017/05/ request_KlimaSeniorinnen.pdf $>$ [hereinafter Request].

6. Paris Agreement, 2(1)(a) <http://unfccc.int/files/essential_background/convention/ application/pdf/english_paris_agreement.pdf $>$.

7. Federal Constitution of the Swiss Confederation (SR [Classified Compilation of Federal Legislation] 101).

8. <http://www.echr.coe.int/Documents/Convention_ENG.pdf>. 


\section{BACKGROUND TO CLIMATE LITIGATION}

Applying different lenses to categorizing climate litigation can provide insights into the international context surrounding the KlimaSeniorinnen case. ${ }^{9}$ For example, a generational lens can be used to understand developments in litigation strategies over time. ${ }^{10}$ The first climate litigation cases were brought primarily in developed countries around the time that the United Nations Framework Convention on Climate Change (UNFCCC), and later the Kyoto Protocol, were adopted. ${ }^{11}$ The next set of cases was spurred by the failure of countries to reach a global agreement at the 2009 Copenhagen Conference of the Parties (COP) to the UNFCCC, alongside growing awareness of climate impacts and/or the development of national climate laws and policies. ${ }^{12}$ The adoption of the Paris Agreement in December 2015 marked the start of the current generation of cases, ${ }^{13}$ which will likely play out through 2020 - when state parties communicate new or updated nationally determined contributions.

Another lens for understanding climate litigation focuses on the target of litigation, namely either governments or private actors. ${ }^{14}$ Lawsuits against governments generally involve challenges to action or inaction with respect to climate and energy laws, policies and decisions. Four recent cases discussed here in chronological order provide important context for the KlimaSeniorinnen case. First, in Urgenda Foundation $v$ the Netherlands - a successful climate case that captured global attention - the

9. Different lenses and frames are used to categorize and analyse climate cases. See eg C Hilson, 'Framing Time in Climate Change Litigation', forthcoming, Oñati Socio-Legal Series $<$ http://opo.iisj.net/index.php/osls/index>; D Klaudt, 'Can Canada's "Living Tree" Constitution and Lessons from Foreign Climate Litigation Seed Climate Justice and Remedy Climate Change?' 31(3) Journal of Environmental Law and Practice (forthcoming June 2018).

10. Hilson (n 9). See also a recent article that analyses the 'first' and 'next generation' of climate litigation: J Peel and HM Osofsky, 'Climate Change Lititgation: Lessons and Pathways' (2017) Judicial Offer's Bulletin published by the Judicial Commission of NSW $99<\mathrm{http} / / / \mathrm{law}$. unimelb.edu.au/_data/assets/pdf_file/0020/2608004/December-article-JOB-final-2017.pdf>.

11. Eg in Petition to the Inter-American Commission on Human Rights Seeking Relief from Violations Resulting from Global Warming Caused by Acts and Omissions of the United States (Inuit Petition), Sheila Watt-Cloutier, on behalf of herself, 62 other named individuals, and all Inuit of the Arctic regions of the United States and Canada, requested the assistance of the InterAmerican Commission on Human Rights (IACHR) in 'obtaining relief from human rights violations resulting from the impacts of global warming and climate change caused by acts and omissions of the United States' in 2005, available at <http://www.inuitcircumpolar.com/ uploads/3/0/5/4/30542564/finalpetitionicc.pdf $>$. The IACHR declined to consider the petition and instead held a hearing in 2007. J Gordon, 'The Inter-American Commission on Human Rights to Hold Hearing after Rejecting Inuit Climate Change Petition' (2007) 7 Sustainable Development Law \& Policy 55.

12. See eg Urgenda (n 1); Juliana (n 1); Leghari (n 1).

13. See eg Greenpeace Nordic (n 1); PUSH Sweden v Government of Sweden in Burger et al. (n 3) 17; Thomson v [New Zealand] Minister for Climate Change Issues in Burger et al. (n 3) $16-17$.

14. Two well-known legal actions targeting private actors are: Lliuya $v$ RWE AG [2015] Az 2 O 285/15 (2015) in Burger et al. (n 3) 21; and Greenpeace Southeast Asia, Philippine Rural Reconstruction Movement, et al., 'Petition to the Commission on Human Rights of the Philippines Requesting for Investigation of the Responsibility of the Carbon Majors for Human Rights Violations or Threats of Violations Resulting from the Impacts of Climate Change' (2015) <http://www.greenpeace.org/seasia/ph/PageFiles/735291/Petitioners-and-Annexes/CCHR-Petition.pdf>. 
Urgenda Foundation and 900 co-plaintiffs argued that the Netherlands was committing a tort of negligence against its citizens by contributing to climate change. ${ }^{15}$ In June 2015, the court held that the Dutch state has an obligation to protect current and future generations from the danger posed by hazardous climate change and is required to take precautionary action by reducing GHG emissions by at least 25 per cent instead of only 17 per cent by the end of $2020 .{ }^{16}$ While the Dutch government announced it would start implementing the verdict, ${ }^{17}$ it also filed an appeal. ${ }^{18}$ A hearing is scheduled for 28 May $2018 .{ }^{19}$

In September 2015, a Pakistani court presiding over Asghar Leghari v Federation of Pakistan issued a first-of-its-kind decision focusing on the need for government action on climate adaptation based on human rights and constitutional protections. A farmer acting in the public interest was awarded two orders forcing the government to present a list of climate adaptation measures and to establish a Climate Change Commission. ${ }^{20}$ The court's innovative approach requires ongoing judicial supervision to ensure progress. $^{21}$

A third exemplary action is Juliana $v$ United States of America, concerning alleged violations of constitutional and public trust rights. Just before the Leghari decision, a group of 21 young people and a climate scientist, as guardian for future generations, sued the US federal government and president for violating their constitutional rights to life, liberty and equal protection as well as their public trust rights to vital natural resources. The youth plaintiffs argue that the US government has violated and continues to violate its constitutional and public trust obligations by committing the US to a fossilfuel-based energy system for more than five decades, despite having knowledge of the grave dangers it poses. ${ }^{22}$ The plaintiffs are seeking a court order directing the government to develop and put in place a 'comprehensive, science-based' ${ }^{23}$ climate recovery plan to dramatically reduce $\mathrm{CO}_{2}$ emissions, phase out fossil fuels and implement natural

15. R Cox, Climate Litigation Precedent: Urgenda Foundation v The State of the Netherlands (CIGI Papers No 79, November 2015) $1<$ https://www.cigionline.org/sites/default/files/cigi_paper_79.pdf>; Marc Loth, 'Climate Change Liability After All: A Dutch Landmark Case' (2016) Tilburg Law Review: Journal on International and Comparative Law 5.

16. Urgenda (n 1) [4.79], [4.83], [5.1].

17. Following the verdict, the newly formed coalition government announced in late 2017 that it would reduce emissions by 49 per cent by 2030 compared to 1990 levels (J Pieters, 'New Dutch Energy Policy Exceeds Europe Requirements', NL Times, 11 October 2017).

18. Government of the Netherlands, 'Cabinet Begins Implementation of Urgenda Ruling but Will File Appeal' (2015) <https://www.government.nl/latest/news/2015/09/01/cabinet-beginsimplementation-of-urgenda-ruling-but-will-file-appeal $>$.

19. Urgenda, 'Dutch Government to Appeal in Groundbreaking Case' $(2015)<\mathrm{http}: / / \mathrm{www}$. urgenda.nl/en/climate-case/>; Urgenda, 'Climate Case' (2017) <http://www.urgenda.nl/en/ climate-case/>.

20. Leghari (n 1) order 4 September 2015.

21. D Estrin, Limiting Dangerous Climate Change: The Critical Role of Citizen Suits and Domestic Courts - Despite the Paris Agreement (CIGI Papers No 101, 11 May 2016) 14 <https://www. cigionline.org/sites/default/files/paper_no.101.pdf>; Leghari (n 1) order 14 September 2015.

22. Juliana $v$ United States of America, First Amended Complaint for Declaratory and Injunctive Relief Case No: 6:15-cv-01517-TC [2015], 1-6, 84-95 <https://www.ourchildrenstrust.org/ s/YouthAmendedComplaintAgainstUS-t9f3.pdf> (hereinafter Amended Complaint).

23. Our Children's Trust et al., 'State Obligations Regarding Children's Rights and Climate Change: Submission to UN Committee on the Rights of the Child' (2016), iii <https://static1. squarespace.com/static/571d109b04426270152febe0/t/57bf0ff5ebbd1afb36a4c4e3/ 1472139275560/OCT+et+al.+CRC+Submission.pdf $>$ (hereinafter Our Children's Trust). 
sequestration measures in order to stabilize the climate system. ${ }^{24}$ The US District Court for the District of Oregon set the trial for 5 February 2018; however the US government defendents petitioned the Ninth Circuit Court of Appeals to direct the District Court to dismiss the case. The Ninth Circuit Court of Appeals rejected the government defendents' petition, and soon after a US Magistrate Judge set the trial for 29 October $2018 .{ }^{25}$

The final example is a landmark case brought by two Norwegian non-governmental organizations (NGOs), Nature and Youth and Greenpeace Nordic Association, in October 2016. They argue that the government's decision to license new oil and gas drilling in the Norwegian Arctic is a violation of the constitutional right to a healthy and safe environment and is inconsistent with the Paris Agreement, which was ratified just 10 days after the licences were granted. The plaintiffs also maintain that there was a lack of administrative due process in the government's decision. ${ }^{26}$ Following the trial, the Oslo District Court delivered the NGOs a partial victory by recognizing that individuals and future generations have a constitutional right to a healthy environment, while finding the government's licensing decision valid; as a result the judgment has been appealed. ${ }^{27}$ One week after the launch of the Norwegian case, KlimaSeniorinnen Schweiz filed their legal request to the Swiss government authorities.

\section{THE SCIENTIFIC BASIS FOR THE KLIMASENIORINNEN REQUEST}

\subsection{Climate science in the context of international climate policy}

The request filed by KlimaSeniorinnen is based on the repors and findings of the Intergovernmental Panel on Climate Change (IPCC), ${ }^{28}$ the Subsidiary Body for Scientific and Technological Advice (SBSTA) of the UNFCCC and the Swiss Federal Department of the Environment, Transport, Energy and Communications (DETEC).

24. Ibid 4-5, 12-13, 68, 94-5; Juliana (n 1) 12-13. See also section 5.2.

25. Our Children's Trust, 'Juliana v U.S. - Climate Lawsuit' (2017) <https://www.ourchildren strust.org/us/federal-lawsuit/>.

26. Greenpeace Nordic (n 1) Introduction, 33-41.

27. V Carlström, 'Greenpeace's Historic Lawsuit against Norway for Arctic Drilling has been Approved for Court', Business Insider Nordic (2017) <http://nordic.businessinsider.com/green peaces-historical-lawsuit-against-norways-government-for-arctic-drilling-has-been-approvedfor-court-2017-2/>; Greenpeace Nordic Association et al. $v$ Norway Ministry of Petroleum and Energy, Judgement, Case No: 16-166674TVI-OTIR/06 [2018] <https://secured-static.green peace.org/norway/Global/norway/Arktis/Dokumenter/2018/Judgement - 4. jan 2017 - Oslo District Court stamped version.pdf?_ga=2.190959790.585114656.1525113204-77230 7806.1516067904>; Greenpeace International, 'Greenpeace and Nature and Youth take the Norwegian Government to the Supreme Court' (2018) <https://www.greenpeace.org/international/ press-release/14527/greenpeace-and-nature-and-youth-take-the-norwegian-government-to-thesupreme-court/>. Norway's Supreme Court ruled that the appeal must first be heard by the intermediary Court of Appeals. Greenpeace Nordic Association et al. $v$ Norway Ministry of Petroleum and Energy, Norwegian Supreme Court, Decision, HR-2018-661-U (Case No 18-043328SIV-HRET) [2018] <https://www.domstol.no/globalassets/upload/hret/avgjorelser/2018/avgjorelser-april-2018/ saknr-hr-2018-661-u.pdf>.

28. The IPCC is an intergovernmental body with 195 member states, established to provide an objective scientific basis for climate change and its impacts on natural and human systems. The IPCC compiles the results of thousands of studies and evaluates them critically following stringent procedures. Its Assessment Reports must be endorsed by all member states. Therefore its reports carry special weight and have been relied upon by courts. The IPCC assesses the risks 
The finding of the IPCC's 2007 risk assessments (published in the Fourth Assessment Report [AR4]) that the risks of temperature rise above $2^{\circ} \mathrm{C}$ are potentially uncontrollable led the parties to the UNFCCC at the Cancun COP in 2010 to establish a $2^{\circ} \mathrm{C}$ temperature target. ${ }^{29}$ Relying on the IPCC's Fifth Assessment Report (AR5) of 2014, the parties to the Paris Agreement committed to confining temperature rise to 'well below $2^{\circ} \mathrm{C}$ ' and to pursuing efforts to keep it at $1.5^{\circ} \mathrm{C}$ (this will be referred to hereinafter as the 'well below $2^{\circ} \mathrm{C}$ ' target). In order to have a 'likely' (ie 66-100 per cent probability) chance of meeting the $2^{\circ} \mathrm{C}$ target, GHG concentrations should not exceed $450 \mathrm{ppm}$ in the year $2100 .{ }^{30}$ This can be achieved only through a sharp decline and subsequent phase-out of net anthropogenic GHG emissions. ${ }^{31}$ A net zero value of $\mathrm{CO}_{2}$ emissions must be achieved between 2055 and 2070 and for the other GHGs between 2080 and $2100 .{ }^{32}$ Calculations in both AR4 and AR5, reflecting the carbon concentration of $450 \mathrm{ppm}$ for 2100, show that industrialized countries such as Switzerland must reduce their emissions by 25 to 40 per cent below 1990 levels by 2020 and by at least 50 per cent by 2030 in order to do their part to stabilize temperature increase at a maximum of $2^{\circ} \mathrm{C}$ at $2100 .^{33}$ Both the scale and the rate of global emission reductions are important in order to comply with the $2^{\circ} \mathrm{C}$ and the 'well below $2^{\circ} \mathrm{C}$ ' targets. If the emission reduction efforts required by 2020 are delayed in full or in part, the reductions required later on will be far greater, resulting in substantial social and economic consequences. ${ }^{34}$ Scenarios planned with a reduction rate not exceeding 3 per cent per year are substantially more cost effective than those requiring higher reduction rates in the future, and thus make actual emission reductions more feasible. ${ }^{35}$ Also, the risks resulting from failing to achieve the $2^{\circ} \mathrm{C}$ or 'well below $2^{\circ} \mathrm{C}$ ' targets are lower. This is all the more true of the $1.5^{\circ} \mathrm{C}$ target, where ' $[\mathrm{t}]$ he window for achieving this goal is small and rapidly closing' ${ }^{36}$

for different levels of GHG emissions, among other matters. It does not take a position on what would be 'safe' levels of warming. See also <https://www.ipcc.ch/organization/organization. shtml>.

29. IPCC, Climate Change 2014: Synthesis Report, Summary for Policymakers, 51-4; Conference of the Parties to the UNFCCC, The Cancun Agreements: Outcome of the work of the Ad Hoc Working Group on Long-term Cooperative Action under the Convention, Decision 1/CP.16 2010 para 4.

30. IPCC Synthesis Report, Summary for Policymakers, [20]-[21]; in October 2017 the concentration of $\mathrm{CO}_{2}$ was $403.96 \mathrm{ppm}$ (NOAA <http://www.esrl.noaa.gov/gmd/ccgg/trends/global. html>).

31. A special IPCC report regarding the net zero limit for a $1.5^{\circ} \mathrm{C}$ target will be available in 2018 . 32. SBSTA, Report on the structured expert dialogue on the 2013-2015 review, Bonn 1-11 June 2015 (FCCC/SB/2015/INF.1) 136; L Clarke, K Jiang, K Akimoto, M Babiker, G Blanford, K Fisher-Vanden, JC Hourcade, V Krey, E Kriegler, A Löschel, D McCollum, S Paltsev, S Rose, PR Shukla, M Tavoni, BCC van der Zwaan and DP van Vuuren, 'Assessing Transformation Pathways', in Climate Change 2014: Mitigation of Climate Change. Contribution of Working Group III to the Fifth Assessment Report of the Intergovernmental Panel on Climate Change (Cambridge University Press, Cambridge/York 2014) 432, Figure 6.7.

33. Request (n 5) 34-7 (see also 38-48). See section 4.2 regarding achieving these reductions domestically.

34. UNEP, Emissions Gap Report 2014, Executive Summary, section $3<$ http://apps.unep.org/ redirect.php?file=/publications/pmtdocuments/-The\%20Emissions\%20Gap\%20Report\%202014: \%20a\%20UNEP\%20synthesis\%20report-November\%202014EGR_2014_Lowres.pdf>.

35. IPCC Synthesis Report (n 30), 84-5, Figure 3.3.

36. J Rogelj, G Luderer, RC Pietzcker, E Kriegler, M Schaeffer, V Krey and K Riahi, 'Energy System Transformations for Limiting End-of-century Warming to below $1.5^{\circ} \mathrm{C}^{\prime}$ ' (2015) 6 Nature Climate Change 519. 
Additionally, Switzerland faces clear climate impacts. If global GHG emissions continue on their current trajectory, Switzerland's temperature increase is expected to be double the global average due to its geographical location. ${ }^{37}$ Between 1961 and 2011, summers became an average of approximately $2.5^{\circ} \mathrm{C}$ warmer and winters by around $1.5^{\circ} \mathrm{C},{ }^{38}$ not only leading to glaciers retreating and permafrost melting, but also to making the water cycle unpredictable and increasing the likelihood of dangerous heatwaves; future heatwaves are expected to be more frequent, longer and more intense. ${ }^{39}$

\subsection{Health effects of climate-induced heatwaves}

Numerous studies have examined the links between climate change, the recent hot summers and health impacts, especially premature deaths. ${ }^{40}$ In the extremely hot summer of 2003, 70000 additional deaths were recorded across Europe compared to any other summer. ${ }^{41}$ In Switzerland the death toll was 6.9 per cent higher than average. ${ }^{42}$ These deaths were not randomly distributed among the population, but had a disproportionate impact on older persons aged 75 to 85 ; women were more affected than men, ${ }^{43}$ and older women with respiratory diseases suffered the most. ${ }^{44}$ The increased number

37. DETEC, Klimapolitik der Schweiz, Erläuternder Bericht zur Vernehmlassungsvorlage, 31 August 2016, 7, <https://www.admin.ch/ch/d/gg/pc/documents/2801/Klimapolitik-derSchweiz-nach-2020_Erl.-Bericht_de.pdf>.

38. FOEN (ed), Klimaänderung in der Schweiz, 32-3, <https://www.bafu.admin.ch/bafu/de/ home/themen/klima/publikationen-studien/publikationen/klimaaenderung-schweiz-2013.html> .

39. Ibid 11-12.

40. For an overview see $\mathrm{L}$ Krummenauer and $\mathrm{C}$ Walther, Klimawandelbedingte Zunahme von Hitzeereignissen und deren Folgen für die Gesundheit in der Schweiz und in Europa (2017, $<$ http://klimaseniorinnen.ch/wp-content/uploads/2017/12/Studie_2017_HitzeSchweiz.pdf>); see also FOEN (ed), Impulse für eine klimaangepasste Schweiz. Erkenntnisse aus 31 Pilotprojekten zur Anpassung an den Klimawandel 32 <https://www.bafu.admin.ch/bafu/de/home/themen/ klima/publikationen-studien/publikationen/impulse-fuer-klimaangepasste-schweiz.html>.

41. JM Robine, SL Cheung, S Le Roy, H van Oyen and FR Herrmann, Report on Excess Mortality in Europe during Summer 2003, February $2007<\mathrm{http} / /$ www.theurbanclimatologist.com/ uploads/4/4/2/5/44250401/mortalityheatwave2003.pdf $>12$.

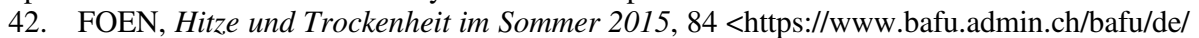
home/themen/klima/publikationen-studien/publikationen/Hitze-und-Trockenheit-im-Sommer2015.html>.

43. Ibid 84; O Thommen Dombois and C Braun-Fahrländer, Gesundheitliche Auswirkungen der Klimaänderung mit Relevanz für die Schweiz, Literaturstudie im Auftrag der Bundesämter für Umwelt, Wald und Landschaft (BUWAL) und für Gesundheit (BAG), November 2004, 33. According to FOEN (n 42) 82-6 most additional deaths in the unusually hot summer of 2015 occurred among the elderly as well, with a slightly higher impact on men, the additional deaths of women being substantially lower than in 2003. FOEN 86 suggests various possible reasons for this finding: chance; different sensitivities of men and women to different types of heatwaves (stronger temperature oscillations versus greater length of heatwaves); women adapting their behaviour better to the heat than men. Even if future research conclusively disproved that older women are more vulnerable than older men, older women would still be part of this most vulnerable group of older persons.

44. D D'Ippoliti, P Michelozzi, C Marino, F deDonato, B Menne, K Katsouyanni, U Kirchmayer, A Analitis, M Medina-Ramón, A Paldy, R Atkinson, S Kovats, L Bisanti, A Schneider, A Lefranc, C Iñiguez and CA Perucci, 'The Impact of Heat Waves on Mortality in 9 European Cities: Results from the EuroHEAT Project' (2010) Environmental health <https://ehjournal.biomedcentral.com/ articles/10.1186/1476-069X-9-37>. 
of deaths during heatwaves cannot be attributed to a 'harvesting effect', namely to the premature death of people already seriously ill. ${ }^{45}$ The causal link between climate change, which is undisputedly already occurring, and premature death is 'likely' (as defined in section 3.1). ${ }^{46}$ Excessive heat also has numerous direct and indirect health impacts. ${ }^{47}$ While heatwaves in Switzerland put other populations such as infants, small children and children at significant risk of heat-related health impacts, current research indicates that older women suffer the highest rate of mortality during periods of extreme temperatures. ${ }^{48}$

\section{THE LEGAL SETTING AND LEGAL ARGUMENTS IN KLIMASENIORINNEN}

\subsection{Developing the case}

\subsubsection{Preliminary analysis}

Following the successful Urgenda verdict, Greenpeace Switzerland requested two of the authors of this article to advise whether it would be possible to bring a similar case challenging Switzerland's inadequate climate legislation and policy, and, if not, whether alternative legal options existed. Swiss law has no provision akin to Book 6, Section 162 of the Dutch Civil Code from which a duty of care to limit emissions can arise even though the damage has not yet been incurred. ${ }^{49}$ Therefore a different litigation approach to seek preventive action had to be devised for Switzerland.

The argument formulated, based on substantive legal research, was that Swiss climate legislation and its implementation are currently insufficient in light of the standards set by both the Constitution and by the ECHR. ${ }^{50}$ The legal analysis argued that Switzerland's current and planned reduction targets -20 per cent below 1990 levels by $2020^{51}$ and 50 per cent by 2030 , with a maximum of 20 per cent of these reductions to be achieved

45. ProClim-Forum for Climate and Global Change, Hitzesommer 2003, Synthesebericht (ProClim, Bern 2005) 16.

46. KR Smith, A Woodward, LD Campbell, DD Chadee, Y Honda, Q Liu, J M Olwoch, B Revich and R Sauerborn, 'Human Health: Impacts, Adaptation, and Co-benefits', in Climate Change 2014: Impacts, Adaptation, and Vulnerability, Part A: Global and Sectoral Aspects. Contribution of Working Group II to the Fifth Assessment Report of the Intergovernmental Panel on Climate Change (Cambridge University Press, Cambridge/New York 2014) 709-54, 721.

47. See eg FOEN (ed), Klimaänderung (n 38) 58-61; Krummenauer and Walther (n 40) 11-15; see also WHO <http://www.who.int/mediacentre/factsheets/fs266/en/>. Direct impacts include, for example, more cases of heat stroke, to which the elderly are more susceptible because of their bodies' poorer temperature regulation, and dehydration; indirect ones include, for example, those due to higher levels of ozone and other air pollutants, which exacerbate cardiovascular and respiratory disease, and of pollen, which triggers asthma.

48. FOPH, Hitzewellen und die Gesundheit von Kindern, 9 November $20162<$ https://www. bag.admin.ch/bag/de/home/themen/mensch-gesundheit/klimawandel-gesundheit/hitzewelle. html>.

49. Urgenda (n 1) [4.35] and [4.88].

50. U Brunner and CC Bähr, 'Klimaverantwortlichkeit der Schweiz', Gutachten erstellt im Auftrag von Greenpeace Schweiz, 18 November 2015, on file with authors.

51. In Urgenda ( $\mathrm{n}$ 1) [4.86] the court found that the State's policy of reducing emissions by 17 per cent by 2020 was below the norm of a $25-40$ per cent reduction for developed countries deemed necessary by climate science and international climate policy. 
by paying for projects abroad - do not correspond to international climate law, which relies heavily on the findings of the IPCC (see section 3.1). ${ }^{52}$ Additionally, the mitigation measures for achieving these reduction targets are incomplete and not sufficiently effective, in particular in the transportation and agriculture sectors. Furthermore, since the reduction targets are not ambitious enough, the mitigation measures will not contribute enough towards the achievement of the $2^{\circ} \mathrm{C}$ and the 'well below $2^{\circ} \mathrm{C}$ ' targets. ${ }^{53}$ Finally Switzerland's planned policy of buying emission reductions abroad to reach its own reduction goals - still a controversial issue ${ }^{54}$ - is a major reason for Switzerland's climate policy failures: the purchase of offsets delays the necessary domestic reductions and thereby risks irreversible failure to achieve the inevitable transition to net zero emissions within the agreed period of time while also significantly increasing future costs. ${ }^{55}$

The research also discussed the types of legal instruments available as possible remedies and recommended challenging Swiss climate legislation and its implementation by focusing on violations of human rights. ${ }^{56}$ The reason for taking a human rights approach was that an especially strong link can be established between climate change and older women's health risks - in the worst case leading to premature death - due to the increase in heatwaves over recent years and the increased likelihood, greater intensity and longer duration of heatwaves in the future.

Once the research was finalized, Greenpeace Switzerland discussed the findings with supporters and allies. Seeking to do more to protect their own lives and health, a few hundred older women formed an association representing the risk profile determined by epidemiology and committed to holding the government accountable. A welcome co-benefit of their action was increased protection of future generations given that under Swiss law future generations have yet to be recognized as holders of human rights. $^{57}$

\subsubsection{The KlimaSeniorinnen request}

Founded in August 2016, the association KlimaSeniorinnen Schweiz filed a request on 25 November 2016 to issue a ruling on real acts in terms of Article 25a(1)(a) APA for 'discontinuation of failures in climate protection'. ${ }^{58}$ The request was addressed to four administrative authorities which had been identified as having failed to fulfil their obligations: the Federal Council, as the highest executive body; DETEC, as the department responsible for the protection and preservation of natural resources and protection against natural hazards; and finally two of DETEC's subordinate administrative units, the Federal Office for the Environment (FOEN) and the

52. Brunner and Bähr (n 50).

53. These findings were published in a peer-reviewed legal journal with a broad audience in order to stimulate wide discussion; see CC Bähr and U Brunner, 'Ist das Schweizer Klimaziel verfassungskonform?' (2016) 25(9) Aktuelle Juristische Praxis (AJP) 1219.

54. Request (n 5) [47]-[48], [106], [321].

55. IPCC, Climate Change 2014: Synthesis Report. Contribution of Working Groups I, II and III to the Fifth Assessment Report of the Intergovernmental Panel on Climate Change Geneva, Switzerland, Figure 3.3. 84 f.; Request (n 5) [53]-[54].

56. Brunner and Bähr (n 50).

57. See A Tschentscher, Article 10 in B Waldmann, EM Belser and A Epiney (eds), Basler Kommentar Bundesverfassung (Helbing Lichtenhahn, Basel 2015) [6].

58. Request (n 5) [3]. 
Federal Office of Energy (FOE). ${ }^{59}$ Respecting the principle of separation of powers, the request addressed only the executive branch and not the legislature.

Specifically, KlimaSeniorinnen demanded that the government should end unlawful inaction inconsistent with the target of limiting the increase in global average temperature to 'well below $2^{\circ} \mathrm{C}$ ' or preferably $1.5^{\circ} \mathrm{C}$ above pre-industrial levels - or at the very least, not letting it exceed $2^{\circ} \mathrm{C}$ - and to take all necessary actions to remedy the situation.

The request lists a number of specific demands, arranged in four groups that encompass omissions regarding targets and measures, and identifying obligations that the respondents are required to fulfil by 2020 or 2030 . The demands include an examination of the duties of the confederation under the constitution and the ECHR; communication to parliament and the public that these duties are not being fulfilled to date and how compliance will be achieved; the development of mitigation measures necessary to achieve the targets; and in particular, the initiation of a preliminary legislative procedure to strengthen emission reduction targets and mitigation measures. The specific demands also include a demand for an end to numerous inactions.

If however the court determines that sufficient remedial measures are not available to bring an end to the unlawful conduct and to fulfil the primary demand, an alternative final demand asks for a declaratory ruling that the Swiss authorities' inactions are illegal. However, the primary goal of the request is that the authorities do more to fight climate change and that they remedy their omissions and failures by taking immediate action.

\subsubsection{Issues of justiciability}

With respect to standing, the scientific evidence that older women have a considerably higher risk of premature death and other health problems due to extreme heatwaves than the average population (see section 3.2 above) was key for the approach taken in Switzerland. ${ }^{60}$ This scientific evidence was the basis for categorizing older women as a 'most vulnerable group' whose human rights the state is required to protect. This correlation also means that older women are 'specifically affected' in terms of Article 48(1)(b) of the Administrative Procedure Act (APA) ${ }^{61}$ which grants locus standi only to persons 'affected more strongly than the general public' and with 'a special, noteworthy, close connection to the matter in dispute'. ${ }^{62}$ Pursuant to Article 48(1)(c) APA, claimants must have an interest that is 'worthy of protection'. According to Swiss case law claimants have to prove that they have a legal or factual interest that is current and practical. ${ }^{63}$ Due to this requirement, it may be easier to demonstrate that older women have 'an interest that is worthy of protection' than is the case with other populations since the existing research suggests that older women are currently suffering the highest rate of mortality during periods of extreme heat. Because the right to appeal serves only to protect specific and current individuals' rights, this approach reduces the risk that an appeal would be deemed to be an actio popularis,

59. Request (n 5) [1].

60. Brunner and Bähr (n 50).

61. SR 172.021.

62. Translation of the standard case law wording, eg FSC (Federal Supreme Court) 139 II 279, [2.2], by authors. See also V Marantelli and S Huber, Article 48 in B Waldmann and $\mathrm{P}$ Weissenberger (eds), VwVG Praxiskommentar zum Bundesgesetz über das Verwaltungsverfahren (Schulthess, Zurich 2016) [10]-[11].

63. FSC 140 II 315, 11/04/2014, [4.2]. 
and thus to be an action that only seeks to ensure the correct application of the law, which is not reviewable in Switzerland. ${ }^{64}$

The argument made by KlimaSeniorinnen was that as an association of women averaging 75 years of age in 2020 - who are therefore particularly vulnerable to heatwaves fuelled by climate change and who would benefit from more stringent climate policies - KlimaSeniorinnen has standing both in its own name and as the representative of its members. This ground of locus standi under Article 48 APA is called (in translation) the 'egoistical right of associations' as opposed to the 'idealistic' right of, for example, environmental organizations fighting in the (public) interest of the environment. ${ }^{65}$ Additionally, in case standing were to be denied to the association, four older women from different parts of the country joined the case in their individual capacity.

Article 190 of the Constitution, which declares legislation passed by parliament to be binding on the Federal Supreme Court (FSC), poses a special hurdle for litigation in Switzerland. The Swiss $\mathrm{CO}_{2} \mathrm{Act}^{66}$ with its inadequate emission reduction targets and mitigation measures is therefore not subject to judicial review. However, as alleged in the request to the Swiss government authorities, Switzerland's climate policy violates not only constitutional rights, but also the human rights guarantees of Articles 2 and 8 ECHR. Since it is possible for the European Court of Human Rights (ECtHR) to hear a dispute regarding human rights violations, Swiss climate legislation is arguably subject to judicial scrutiny, based on Articles 6(1) and 13 ECHR ${ }^{67}$ Article 6(1) ECHR, which sets out the fundamental right to a fair trial, is directly applicable in Switzerland. The FSC therefore conducts constitutional reviews in such cases despite Article 190 of the Constitution, and accordingly recognizes that an entitlement to domestic judicial protection can arise directly from international law, in particular from Article 6(1) ECHR. ${ }^{68}$

In order to rely upon Article 6(1) ECHR, one must first demonstrate there is a 'civil dispute'. ${ }^{69}$ According to ECtHR case law, this term also covers administrative decisions by governments, provided they directly infringe on civil rights and obligations. ${ }^{70}$ The FSC has acknowledged that disputes concerning protection against pollution fall into the category of 'civil disputes' if applicants face serious risks to their health or physical integrity as protected by Article 8 of the ECHR. ${ }^{71}$ In addition the 'dispute' over a civil 'right' needs to be 'recognized under domestic law', at least on arguable grounds. ${ }^{72}$

64. For details see Marantelli and Huber (n 62) [10]-[12].

65. Marantelli and Huber (n 62) [20].

66. Federal Act on the Reduction of $\mathrm{CO}_{2}$ Emissions (SR 641.71).

67. Article 13 ECHR (right to effective remedy) is invoked in the Request (n 5) in the case that the Federal Council were to issue a ruling. However, because DETEC answered the applicants' request (3.1.4), Article 6(1) ECHR is applicable and Article 13 ECHR relating to any kind of national authority is no longer relevant.

68. H Keller and Y Weber, 'Folgen für den Grundrechtsschutz und verfassungsrechtliche Gültigkeit der "Selbstbestimmungsinitiative"' (2016) 25(8) AJP 1010. See FSC 125 II 417, 26/07/1999, [4c-e].

69. DJ Harris, M O'Boyle, EP Bates and CM Buckley, Harris, O'Boyle \& Warbrick, Law of the European Convention on Human Rights (3rd edn, Oxford University Press, Oxford 2014) 378-90.

70. See eg $H v$ United Kingdom, No 9580/81, 08/07/1987, 69; Rasmussen v Denmark, No 8777/79, 28/11/1984, 32; FSC 130 I 388, 13/10/2004, [5.1].

71. Judgment FSC 1A.310/2000, 03/04/2001, [3c].

72. Boulois v Luxembourg, No 37575/04, 03/04/2012, [90]. 
The condition that the 'civil dispute' be of a 'genuine and serious nature' ${ }^{73}$ requires more than a 'tenuous connection or remote consequences' between the right in question and the results of the proceedings. ${ }^{74}$ In KlimaSeniorinnen the link between climate change and risks to life and health for older women has been scientifically established; evidently, the risk of harm to these women would be markedly reduced if the state took the necessary steps to reduce GHG emissions.

Aside from the obstacle created by Article 190 of the Constitution, which can be overcome if applicants claim a violation of ECHR guarantees, there is a second hurdle in procedural law: the contested acts of Switzerland (see section 4.1.2) were not formal rulings and therefore could not be appealed directly. ${ }^{75}$ The wide variety of these acts concerning the implementation and application of the law by Swiss authorities were administrative actions or inactions, which have no binding legal consequences for individual cases. Such administrative actions or inactions are termed 'real acts'. Because they can still infringe the rights and obligations of private individuals, if challenged by a person with standing, these acts must be examined by a court. Article $25 a$ APA was introduced for such situations involving not a ruling, but 'real acts'. The request for issuance of a ruling on such acts opens the path to the FSC as the final domestic authority in cases that can be brought to the ECtHR. ${ }^{76}$ Such a request may ask for the issuance of a ruling to refrain from, to discontinue or to revoke unlawful acts or to remedy the consequences of such acts, provided that a solution is possible. It is established that a ruling on real acts can also be requested concerning unlawful state inaction. ${ }^{77}$ In such cases, the request must seek the implementation of necessary measures.

\subsubsection{The status of KlimaSeniorinnen}

The senior women were aware of the numerous potential stumbling blocks they would face in bringing not only the first climate case based on human rights in Switzerland, but a claim with an innovative legal strategy. The procedural pathway chosen and the different requests for legal remedy left many options for the respondents' reaction.

The plaintiffs anticipated (based on Article 47(6) $\mathrm{GAOA}^{78}$ ) that DETEC would answer their request on behalf of the other three respondents. In its 25 April 2017 ruling, ${ }^{79}$ DETEC denied standing, alleging the applicants' rights had not been affected as required by Article $25 a$ APA, and did not enter into the case. DETEC did not discuss the health risks or the asserted violations of constitutional and human rights, but instead claimed

73. Benthem v Netherlands, No 8848/80, 23/10/1985, [32]; FSC 130 I 388, 13/10/2004, [5.1].

74. Le Compte, Van Leuven and De Meyere v Belgium, Nos 6878/75 and 7238/75, 23/06/ 1981, [47].

75. Article 44 APA; rulings: Article 5 APA.

76. For details see I Häner, 'Article 25a', in B Waldmann and P Weissenberger (eds), $V w V G$ Praxiskommentar zum Bundesgesetz über das Verwaltungsverfahren (Schulthess, Zurich 2016) 3, fn 9.

77. FSC 140 II 315, 11/04/2014, [2.2].

78. Article 47(6) Government and Administration Organisation Act (SR 172.010) provides for the responsible department to decide in lieu of the Federal Council in case international law guarantees access to a court, because appealing a ruling of the Federal Council is in general excluded according to Article 189(4) of the Constitution. The other two authorities involved are subordinate to DETEC.

79. See <http://klimaseniorinnen.ch/wp-content/uploads/2017/11/Verfuegung_UVEK_ Abschnitt_C_English.pdf> for an unofficial translation of DETEC's reasons. 
that the applicants were asking for worldwide action for everyone's benefit (actio popularis) and argued that this concern must be addressed through legislation, not rulings. DETEC explicitly stated it was the competent authority; separation of powers rightly was not at issue.

At its extraordinary general meeting on 23 May 2017, KlimaSeniorinnen decided to appeal the ruling. The appeal was filed at the Federal Administrative Court on 26 May 2017 and is still pending at the time of writing.

Both the appeal concerning the issue of standing and the substantive case itself, once DETEC issues a decision on the merits, could go up to the FSC and even to the ECtHR.

\subsection{Swiss climate law and the constitution in the context of international law and climate science}

Switzerland, as a party to the UNFCCC, has recognized the $2{ }^{\circ} \mathrm{C}$ target based on the 2010 COP decision and implemented it in Article 1(1) $\mathrm{CO}_{2}$ Act. ${ }^{80}$ Switzerland has also recognized the need for a reduction of 25 to 40 per cent below 1990 levels by 2020 to reach the $2^{\circ} \mathrm{C}$ target, but has not implemented these reductions in the $\mathrm{CO}_{2}$ Act. ${ }^{81}$ On 16 June 2017 the Swiss parliament approved the Paris Agreement and thus also the target of 'well below $2^{\circ} \mathrm{C}$ ' ${ }^{82}$ The government is now preparing climate legislation for post-2020, ${ }^{83}$ but the current proposal with compulsory reduction of Swiss emissions by 50 per cent - only 30 per cent of which must be in Switzerland, with the option of reducing another 20 per cent abroad - is clearly not ambitious enough in the light of scientific findings and the principle of common but differentiated responsibilities to avoid dangerous climate change. ${ }^{84}$ In this context it is important that the COP decision adopting the Paris Agreement 'notes with concern' 85 that the estimated aggregated GHG emission reductions in 2025 and 2030 resulting from intended nationally determined contributions (INDCs) are insufficient to achieve the $2^{\circ} \mathrm{C}$, let alone the $1.5^{\circ} \mathrm{C}$ target and that it 'also notes that much greater emission reduction efforts will be required than those associated with the intended nationally determined contributions in order to hold the increase in the global average temperature to below $2^{\circ} \mathrm{C}$ above pre-industrial levels' ${ }^{86}$

80. For an in-depth assessment of Swiss $\mathrm{CO}_{2}$ legislation see Bähr and Brunner (n 53).

81. According to Article 3(1) of the $\mathrm{CO}_{2}$ Act domestic GHG emissions 'must be reduced overall by 20 per cent as compared with 1990 levels, by 2020 '.

82. <https://www.parlament.ch/de/search-affairs-advanced> No 16.083 .

83. <https://www.bafu.admin.ch/bafu/de/home/themen/klima/dossiers/zukuenftige-klimapoli tik-vernehmlassung.html\#956714133> for the current status; draft for consultation: <https:// www.admin.ch/ch/d/gg/pc/documents/2801/Klimapolitik-der-Schweiz-nach-2020_EntwurfCO2-Gesetz_de.pdf >; results of consultation: <https://www.admin.ch/ch/d/gg/pc/documents/ 2801/Klimapolitik-der-Schweiz-nach-2020_Ergebnisbericht-V2_de.pdf $>$.

84. See Article 3(1) and (2) of the draft (ibid), 2.1 at fn 32 and Climate Action Tracker, Switzerland, 18 September 2017, rating the country's INDC 'insufficient' <http://climateactiontracker.org/ countries/switzerland.html>.

85. Decisions adopted by the Conference of the Parties (Paris Agreement, FCCC/CP/2015/10/ Add.1, 29 January 2016) 17.

86. Ibid. The COP also invited the IPCC to 'provide a special report in 2018 on the impacts of global warming of $1.5^{\circ} \mathrm{C}$ above pre-industrial levels and related global greenhouse gas emission pathways' (ibid 21). 
A challenge that remains for the applicants is to show that the extensive purchase of emission reductions abroad is not a sufficient means to prevent dangerous climate change and protect human rights although Article 6.4 of the Paris Agreement in principle permits such an approach. The case argues that since all countries must reduce their emissions to meet the 'well below $2{ }^{\circ} \mathrm{C}$ ' target, each country must pursue a path that ensures achieving its net zero emission target within the required time. ${ }^{87}$ Furthermore, ongoing purchases of emission reductions abroad will likely lead to lower emission reductions domestically: states selling - assumingly cost-effective - emission reductions are likely to fail in later reducing their own - assumingly more expensive - emissions, which in turn would thwart the efforts made to achieve the global (well below) $2^{\circ} \mathrm{C}$ target. ${ }^{88}$

These targets, stated in the UNFCCC and the Paris Agreement, are arguably legally binding ${ }^{89}$ because according to Article 18(a) of the Vienna Convention on the Law of Treaties ${ }^{90}$ states are required 'to perform in good faith treaties to which they are a party'. This obligation, as well as the customary international law principle of no harm, requires states to ensure that activities within their jurisdiction do not cause environmental harm to other states. ${ }^{91}$ The 'well below $2^{\circ} \mathrm{C}$ ' target may possibly be the minimum due diligence standard required of all states today. ${ }^{92}$ The applicants are not however invoking international law to hold the Swiss authorities accountable, but are rather using it to help interpret the state's duties under national law and the ECHR.

Three provisions of the Constitution are relevant to interpreting Switzerland's duties in the field of climate protection. The first, the 'sustainable development' provision in Article 73 of the Constitution, is understood as a programmatic clause and not as a directly applicable clause. ${ }^{93}$ This means no one can seek legal protection under this provision. Yet it is a trendsetting value-based constitutional provision, expressing an 'emphatically' desired constitutional principle to be considered in formulating and applying the law. ${ }^{94}$

Second, the precautionary principle in terms of Article 74(2) of the Constitution as a fundamental principle of environmental law ${ }^{95}$ must always be taken into account as

87. Request (n 5) [47].

88. See below at note 109 .

89. See discussion in eg Bähr and Brunner (n 53) 1222.

90. <https://treaties.un.org/doc/publication/unts/volume\%201155/volume-1155-i-18232-english. pdf>.

91. RV Percival, 'International Responsibility and Liability', in S Alam, MJ Hossain Bhuiyan, MT Chowdury and EJ Techera (eds), Routledge Handbook of International Environmental Law (Routledge, Abingdon 2013) 684; the no-harm rule can be attributed to the Trail Smelter Arbitration (United States v. Canada, 04/16/1938 and 03/11/194).

92. R Verheyen, Climate Change Damage and International Law: Prevention Duties and State Responsibility (Brill, Leyden 2005) 191, assuming that she would refer to the Paris Agreement today.

93. A Griffel, Die Grundprinzipien des schweizerischen Umweltrechts (Schulthess, Zurich 2001) 37; L Mader, 'Die Umwelt in neuer Verfassung?' (2000/2) URP [Umweltrecht in der Praxis, Zurich] 108; R Mahaim, Le principe de durabilité et l'aménagement du territoire (Schulthess, Geneva 2014) 91-3.

94. R Morell and KA Vallender, 'Art. 73', in B Ehrenzeller et al. (eds), Die schweizerische Bundesverfassung (Schulthess, Zurich 2014) [29], [31]. Regarding the importance of sustainable development for reaching intergenerational justice see A Flueckiger, 'Droits de l'homme et environnement', in M Hertig Randall and M Hottelier, Introduction aux droits de l'homme (Schulthess, Geneva 2014) 617.

95. A Griffel, 'Art. 74', in B Waldmann and EM Belser and A Epiney (eds), Bundesverfassung (Helbing, Basel 2015) [32]. This is also a fundamental principle of international environmental law. 
a generally directly applicable clause when considering environmental protection. ${ }^{96}$ This principle involves 'prevention' (requiring scientific evidence regarding harmfulness of a behaviour, substance or situation) as well as 'precaution' (requiring no such evidence, though requiring sufficient probability). ${ }^{97}$ Climate change today is not a matter of precaution, but one of prevention: preventing an acknowledged risk. ${ }^{98}$ The key function of the precautionary principle as a decision-making rule means there is no justification for state inaction even if there is no scientific certainty concerning the measures with which to resolve the problem of climate change. ${ }^{99}$ Though the Swiss FSC attaches high priority to the precautionary principle ${ }^{100}$ there is no requirement to avoid all conceivable risks. Considering the proportionality principle of Article 5(2) of the Constitution, ${ }^{101}$ and applying the FSC's 2013 decision on the Mühleberg nuclear power station ${ }^{102}$ to the climate sector, the following three-step system emerges. (1) If the precautionary principle and scientific evidence are both taken into account, risks are to be considered 'absolutely inadmissible' if they do not comply with the global 'well below $2{ }^{\circ} \mathrm{C}$ ' target. (2) The risks continuing to exist must be limited through a precautionary approach provided such measures are proportionate. (3) In so far as the remaining risks cannot be limited by proportionate means, they must be dealt with through simultaneously taken adaptation measures.

Third, Article 10(1) of the Constitution guarantees the right to life, covering both the deprivation of and threats to life, and thus covers protection in situations in which the risk to life is long-term (eg increased mortality due to heatwaves). Switzerland's obligation to protect, which applies both in situations of concrete impairment of fundamental rights (ie at least a risk to life) and at least a reasonable probability of such impairment, ${ }^{103}$ requires the state to put in place indispensable protective measures such as adequate environmental legislation. The obligation to protect the applicants as members of a 'most vulnerable group' due to their significantly higher risk of mortality during heatwaves ${ }^{104}$ is based on the increase in the number and intensity of heatwaves fuelled by climate change and on the likelihood of the further increase, greater intensity and longer duration of such periods.

In Mühleberg (2014), the FSC considered a 'remote probability of occurrence of damage' sufficient to give rise to the legislature's duty to protect residents near nuclear power stations, considering the severity and extent of possible impairments of fundamental rights through the peaceful use of nuclear energy. ${ }^{105}$ This holding must apply a fortiori in the present case because climate change has undisputedly already begun

96. U Marti, Das Vorsorgeprinzip im Umweltrecht (Schulthess, Geneva 2011) 149.

97. A Griffel and H Rausch, Kommentar zum Umweltschutzgesetz, Ergänzungsband (Schulthess, Zurich 2011) Art 1 [15].

98. JE Viñuales, The Paris Climate Agreement: An Initial Examination (2016) <https://ssrn. com/abstract $=2704670>$.

99. Griffel and Rausch (n 97) [19]. See also eg FSC 126 II 399, 30/08/2000, [4b]; 124 II 219, 01/04/1998, [8a]; $117 \mathrm{Ib} 28,06 / 03 / 1991$, [6a].

100. FSC 132 II 305, 11/04/2006, [4.3]; Griffel and Rausch (n 97) [1].

101. FSC 131 II 431, 07/04/2005, [4.1].

102. FSC 139 II 185, 28/03/2013, [11.3].

103. B Waldmann, 'Art 35' in B Waldmann, EM Belser, A Epiney (eds), Bundesverfassung (Helbing, Basel 2015) [43].

104. Infants, small children and children experience health problems during heatwaves, which arguably interferes with their right to privacy (Article 13 of the Constitution). However, unlike Article 10 (right to life), Article 13 of the Constitution does not yet entail positive obligations. 105. FSC 140 II 315, 11/04/2014, [4.8]. 
and is 'likely' to result in additional premature deaths in the future. Moreover, the larger the group of people negatively affected, the more effective it is to protect through fundamental rights. ${ }^{106}$ If the confederation assumed its obligation to protect, this would benefit the general population in addition to the applicants; however this fact does not alter the obligation in any way, DETEC's claim to the contrary notwithstanding.

Overall, the state must take all necessary legal and practical measures to protect constitutional rights and to put in place an appropriate administrative framework and budget (see section 4.3 below for a discussion of ECHR guarantees). The minimum target of keeping the temperature rise to 'well below $2^{\circ} \mathrm{C}$ ' is non-negotiable, and there is no margin of appreciation. The obligation of the state to protect 'most vulnerable groups' from threats to life by natural disasters is no less powerful than its duty to apply the precautionary principle, according to which the state must protect 'the people' (ie every person) preventively in their natural environment. Considering the scope of the obligation to protect, the state's obligation to respect international law (Article 5(4) of the Constitution) is significant regarding compliance with international law, but particularly significant is the fact that the ECtHR regularly considers international environmental standards and principles such as the no-harm rule, the precautionary principle, United Nations (UN) reports and other authoritative reports and publications when determining the obligation to protect. ${ }^{107}$ In the present case, the scope of the obligation to protect under national law or under the ECHR cannot be understood separately from the new internationally agreed goal of keeping warming to 'well below $2^{\circ} \mathrm{C}$ ' while pursuing efforts to limit it to $1.5^{\circ} \mathrm{C}$.

In particular, an alleged absence of suitable measures for protecting the affected population is no justification to interfere with Article 10(1) of the Constitution. There are many ways the government could satisfy the principle of proportionality by simply implementing measures to reduce emissions (eg a $\mathrm{CO}_{2}$ levy on motor fuels or promoting electromobility) or by more closely regulating the agricultural sector (eg a $\mathrm{CO}_{2}$ levy on meat products ${ }^{108}$ ). This applies for 2020 as well as for the GHG reduction period through 2030. ${ }^{109}$ Remarkably, the draft for consultation on a new $\mathrm{CO}_{2}$ Act post-2020 of August $2016^{110}$ shows no increased ambition to reduce GHG emissions, ${ }^{111}$ although economical and readily available measures exist. ${ }^{12}$ The current plan is to reach the domestic emission reduction target by largely continuing the existing inadequate measures. ${ }^{113}$

106. M Schefer, Die Beeinträchtigung von Grundrechten. Zur Dogmatik von Art. 36 BV (Stämpfli, Bern 2006) 50.

107. Borysiewicz v Poland, No 71146/01, 01/07/2008, [53]; Tătar v Romania No 67021/01, 27/01/2009, [95], [120]. See also Council of Europe, Manual on Human Rights and the Environment (Council of Europe, Strasbourg 2012) 149.

108. CC Bähr, 'Greenhouse Gas Taxes on Meat Products: A Legal Perspective' (2015) 4(1) Transnational Environmental Law 172.

109. See Request (n 5) [43]-[46] for more examples.

110. See notes 37 and 78 above.

111. See Request (n 5) [106], [136] for a more detailed discussion.

112. See eg NHStern, The Economics of Climate Change (Cambridge University Press, Cambridge/ New York 2007); NH Stern, Why Are We Waiting? The Logic, Urgency, and Promise of Tackling Climate Change (MIT Press, Cambridge 2015); for Switzerland: <https://www.bafu.admin.ch/bafu/ de/home/themen/klima/dossiers/dekarbonisierung-kohlenstoffarme-aera.html>.

113. DETEC (n 37) 3, 28. 


\subsection{The ECHR and climate change}

As already noted, the applicants are not relying on Swiss law alone to establish their claims, but are also invoking two ECHR guarantees. This is possible because Switzerland is a party to the Convention, and is important legally given the Swiss rules on justiciability.

\subsubsection{Article 2 ECHR (right to life)}

The right to life in terms of Article 2 ECHR is similar to Article 10(1) of the Swiss Constitution. According to the case law of the ECtHR, the right to life obligates the parties to the Convention to contribute positively to the protection of life, ${ }^{114}$ if necessary by imposing obligations upon third parties. ${ }^{115}$ The state must take all proportionate measures to protect the lives of those within its jurisdiction. ${ }^{116}$ In the context of the environment, this means that Article 2 ECHR comes into play when certain activities are so harmful that they endanger a person's life. Neither Article 2 ECHR nor Article 10 of the Constitution requires death to occur in order to establish such endangerment. ${ }^{117}$

As argued above, climate change has created an especially vulnerable population (a 'most vulnerable group'), namely older women. Under Article 2 ECHR the state is subject to a special obligation to protect them from the life-threatening consequences of further climate warming. The senior women argue that it would be incomprehensible if the state had no duty to specifically protect against the (existential) risks of climate change. If the climate sector is indeed an area in which state protection duties apply, then this applies at least to older women and thus to the applicants as members of this most vulnerable group. In order to abide by its obligation to protect under Article 2 ECHR, the state must prevent threats to the right to life, including threats from environmental disasters. To this end, it must establish the necessary regulatory, ${ }^{118}$ administrative and financial regimes. ${ }^{119}$ These measures must take into account the special circumstances of a particular situation and the level of risk. ${ }^{120}$

The senior women argue that the confederation must ensure that the targets relating to the scientific bases, set out in section 3.1 (above) of the present article, are met. The obligation of the state to protect 'most vulnerable groups' of the population against threats to life by natural disasters is at least as important as the state's duty to apply the precautionary principle. Moreover, the scope of the obligation to protect according to national law or the ECtHR cannot be understood separately from the internationally agreed 'well below $2^{\circ} \mathrm{C}$ ' target, which is informed by the IPCC's Fifth Assessment Report. ${ }^{121}$

114. Council of Europe (n 107) 18; LCB v the United Kingdom, No 23413/94, 09/06/1998, [36]; Paul and Audrey Edwards v the United Kingdom, No 46477/99, 14/03/2002, [54]; Öneryildiz v Turkey [GC], No 48939/99, 30/11/2004, [71]; Budayeva and Others v Russia, Nos 15339/02 and others, 20/03/2008, [128].

115. Osman $v$ the United Kingdom, No 23452/94, 28/10/1998, [115]-[116]; Council of Europe (n 107) 18.

116. Council of Europe (n 107) 18.

117. Ibid 35.

118. Regarding regulatory (in)action and Swiss law see Flueckiger (n 94) 610; Waldmann (n 103) [49].

119. Öneryildiz (n 114) [89]; Budayeva (n 114) [129].

120. Öneryildiz (n 114) [90]; Budayeva (n 114) [132].

121. See note 28 above. 
Besides the harmfulness of environmentally damaging activities, the scope of the obligation to protect also depends on the foreseeability of the risk to life. ${ }^{122}$ On various occasions the ECtHR has expressed its view regarding the risk of such harm. It has sometimes used the term "likely' ${ }^{\prime 23}$ however without defining it further. The ECtHR therefore leaves the question largely open concerning to what extent a 'causal connection' must be proven between a given harm and a state's action or inaction. ${ }^{124}$ While causation can be established between global GHG emissions and climate change impacts in general, the ability to link GHG emissions from a particular country to a climate event such as a heatwave is still developing due to the inherent complexity and global nature of the climate system as well as the collective action problem. ${ }^{125}$ However, this difficulty should not prevent the applicants from seeking and receiving a legal remedy, because otherwise a legal vacuum would arise in this area so critical for humanity. The applicants allege that it suffices to show that the GHG emissions are causing climate change, fuelling impacts and putting them at risk $;{ }^{126}$ this is supported by the IPCC's findings that the causal link between climate change, which is undisputedly already occurring, and premature deaths is 'likely'. ${ }^{127}$

In environmental matters, the ECtHR normally gives states a wide margin of appreciation due to their proximity to the specific environmental problems. ${ }^{128}$ Because of the global nature of climate change, the applicants argue that room for the 'proximity' that usually requires and justifies the margin of appreciation is limited. They conclude that a state is not acting within its margin of appreciation when its emission target does not meet the $2{ }^{\circ} \mathrm{C}$ or 'well below $2^{\circ} \mathrm{C}$ ' target (section 3.1 above) and argue that only choices concerning more stringent emission targets and the types of measures fall within a state's margin of appreciation. ${ }^{129}$

The ECtHR has on various occasions assumed a general positive obligation to protect in the context of dangerous activities, for example radioactivity ${ }^{130}$ or waste disposal facilities. ${ }^{131}$ The duty to protect was also at issue in cases regarding chemical factories with toxic emissions ${ }^{132}$ and asbestos, where the ECtHR in Brincat and Others $v$ Malta found that the state breached Articles 2 and 8 ECHR because Malta's legislation violated its duties to protect. ${ }^{133}$

122. Öneryildiz (n 114) [93], [101]; LCB (n 114) [37]-[41].

123. Öneryildiz (n 114) [93]; Budayeva (n 114) [140], [147]; LCB (n 114) [38]. See section 3.1 for the IPCC's definition of 'likely'.

124. K Braig, Umweltschutz durch die Europäische Menschenrechtskonvention (Helbing, Basel 2013) 263. See eg Di Sarno and Others v Italy, no 30765/08, 10/01/2012, and H Keller and L Cirigliano, 'Grundrechtliche Ansprüche an den Service Public: Am Beispiel der italienischen Abfallkrise' (2012/9) URP 831, 840.

125. IPCC, Synthesis Report (n 30) 17.

126. Request (n 5) [197]-[199]. See also Urgenda (n 1) [4.90]. For further discussion of causality see eg ERG SpA and others v Ministero dello Sviluppo economico and others, No C-378/08, 09/ 03/2010; M Peeters, 'The Regulatory Approach of the EU in View of Liability for Climate Change Damage' in M Faure and M Peeters (eds), Climate Change Liability (Edward Elgar, Cheltenham 2011) 131.

127. Smith et al. (n 46).

128. Council of Europe (n 107), 31.

129. Request (n 5) [159].

130. $L C B$ (n 114) [36] ff.

131. Öneryildiz (n 114) [71].

132. Guerra and Others $v$ Italy, No 14967/89, 19/02/1998, [60].

133. Brincat and Others v Malta, Nos 60908/11 and others, 24/07/2014. 
Regarding inadequate prevention of environmental disasters, the ECtHR has repeatedly found violations of Article 2 ECHR, for example concerning the failure to adequately protect against mudslides. ${ }^{134}$ The court recently determined that a state has an obligation to protect against dangers to life associated with earthquakes. The summary of $M$ Özel and Others $v$ Turkey, compiled by the ECtHR, states:

The instant case was noteworthy in that it represented the first occasion on which the Court found Article 2 to be applicable to the loss of life resulting from an earthquake. The Court accepted that the authorities have no control over the occurrence of earthquakes. It observed, however, that where an area is prone to earthquakes Article 2 requires the authorities to adopt preventive measures so as to reduce the scale of the disaster created by an earthquake and to strengthen their capacity to deal with it. ${ }^{135}$

In contrast to sudden-onset disasters like earthquakes, global climate change with the associated substantial increase in heatwaves in Switzerland is a slow-onset disaster, which has been scientifically documented as being not just likely, but already underway. Accordingly, climate change-induced heatwaves are a real threat. Metaphorically speaking, the earth has already begun to shake, and the senior women are arguing that it is the state's duty to, as it were, get them out of harm's way from the destructive effects on their lives and health that would certainly occur in the absence of preventive measures. ${ }^{136}$ The harmfulness of the excessive emission of GHGs in general and for the applicants in particular is immense. On the question of whether Swiss GHG emissions are excessive, the ECtHR would be expected to refer to international law and to the work of the IPCC as well as to the precautionary principle (sections 3.1 and 4.2 above) and to examine the Swiss climate target against this backdrop. With a particular view to $M O ̈$ zzel and Others $v$ Turkey, the extensive past and future scientific work of the IPCC helps justify a positive obligation to protect based on the assessed risk of damage occurring. The inactions of the Swiss government authorities, regarding the domestic emission reduction targets necessary to avoid irreversible global change, are alleged by the applicants to violate Article 2 ECHR. ${ }^{137}$

\subsubsection{Article 8 ECHR (right to respect for private and family life)}

The ECtHR has decided various cases under Article 8 ECHR (right to respect for private and family life) ${ }^{138}$ and explicitly found a positive state obligation to protect derived from this guarantee. ${ }^{139}$ Although Article 8(1) ECHR does not expressly guarantee the right to a clean environment, the obligation to protect includes environmental damage $^{140}$ that adversely affects health, physical integrity or private and family life, and also well-being. ${ }^{141}$ Unlike Article 2 ECHR and Article 10 of the Constitution, a danger to life is not a precondition. While Article 2 ECHR does not allow for any

\section{Budayeva (n 114).}

135. ECtHR, Overview of the case law of the European Court of Human Rights $2015<$ www. echr.coe.int/Documents/Short_Survey_2015_ENG.pdf> 21, emphasis added.

136. Request (n 5) [156].

137. Request (n 5) [160].

138. $M$ Özel and Others v Turkey, No 14350/05, 17/11/2015.

139. See references to case law in Request (n 5) [169].

140. López Ostra v Spain, No 16798/90, 09/12/1994.

141. Fadeyeva v Russia, No 55723/00, 09/06/2005, [68]; Kyrtatos v Greece, No 41666/98, 22/05/2003, [52]; Dubetska and Others v Ukraine, No 30499/03, 10/02/2011, [105]. 
justifications for states not fulfilling their obligation to protect, the issue of potential justification does have to be considered when applying Article 8 ECHR (and Article 10 Constitution).

The applicants accordingly argue that there is no public interest conflicting with the state assuming its obligation to protect towards them. ${ }^{142}$ When weighing interests, one should consider that almost everyone will at some point belong to the group of elderly people severely impacted by the consequences of global warming. It follows that a residual risk cannot be accepted if global warming exceeds the 'well below $2^{\circ} \mathrm{C}$ ' target. A proportionality assessment must be carried out to examine whether the measures taken by the authorities are reasonable in light of the evidence. ${ }^{143}$ The applicants argue that the response is not proportionate because the emission reduction targets and the reduction measures are insufficient and inadequate. ${ }^{144}$ In addition, they contend that the protection of human health in particular is of great legal ${ }^{145}$ importance and arguably outweighs countervailing economic interests. ${ }^{146}$

The applicants further assert that the potentially inadequate climate policies of other countries provide no justification for Switzerland's own failures, ${ }^{147}$ and that such policies do not qualify as force majeure, nor does the behaviour of Swiss companies or citizens. Switzerland has every opportunity to make its contribution to the 'well below $2^{\circ} \mathrm{C}$ ' target, as is expected from scientific and international law perspectives. There is no question of a conflicting insurmountable force or unforeseen circumstances. ${ }^{148}$

The fact that Switzerland is a comparatively small country carries little weight because the reduction levels calculated by the IPCC can lead to compliance with the $2^{\circ} \mathrm{C}$ or 'well-below $2^{\circ} \mathrm{C}$ ' targets only if all concerned parties meet them. ${ }^{149}$ If all governments act like Switzerland, global warming will clearly exceed $2^{\circ} \mathrm{C} .{ }^{150}$ At present, not only the current emission reductions, but also the parties' pledges for the period after 2020 appear insufficient for compliance with even a $2^{\circ} \mathrm{C}$ target: at best, the emission reductions offered in Paris will lead to a global average temperature increase of $2.7^{\circ} \mathrm{C}$ by 2100 , which would have devastating consequences. ${ }^{151}$ In addition, each tonne of $\mathrm{CO}_{2}$ warms up the climate. For this reason, all countries have to take measures to reduce GHG emissions to the greatest possible extent. A state cannot therefore disregard its obligation to take precautionary measures by arguing that it makes only a 'minor contribution'. ${ }^{152}$ Furthermore, the per capita emissions in Switzerland are equal to or slightly higher than in neighbouring countries if grey emissions are

142. Request (n 5) [175]-[176], see also [137].

143. Dubetska (n 141) [105]; Fadeyeva (n 141) [88]-[89], [92].

144. Request (n 5) [134]-[136], [176].

145. Braig (n 124) 249.

146. Request (n 5) [138], [176].

147. Request (n 5) [139], [177].

148. Request (n 5) [166], [178].

149. Request (n 5) [142]-[144].

150. As stated for example by Judgment Federal Administrative Court, A-1300/2015, 30/03/ 2016, 14.9.2.

151. Climate Action Tracker, Switzerland <http://climateactiontracker.org/countries/ switzerland>.

152. Climate Action Tracker, 'Climate Pledges will Bring $2.7^{\circ} \mathrm{C}$ of Warming, Potential for More Action', 8 December 2015 <http://climateactiontracker.org/news/253/Climate-pledgeswill-bring-2.7C-of-warming-potential-for-more-action.html>. 
also considered. ${ }^{153}$ Switzerland must live up to its responsibility ${ }^{154}$ to 'take the lead by undertaking economy-wide absolute emission reduction targets' (Article 4.4 of the Paris Agreement). ${ }^{155}$

\section{HOW KLIMASENIORINNEN MAY INFORM FUTURE CLIMATE LITIGATION}

In this final section, we discuss the ways in which the arguments made in the KlimaSeniorinnen case may inform further climate litigation in other jurisdictions. Climate change is a global issue, and so are the related problems and solutions, including legal ones. Courts in different jurisdictions have to find answers to similar questions. ${ }^{156}$ This has created a situation where the legal discourse concerning climate change is transcending jurisdictional boundaries, be it in courtrooms or amongst communities, NGOs and lawyers. ${ }^{157}$ KlimaSeniorinnen has become a part of the global conversation. The insights from KlimaSeniorinnen are also bolstered by the positive developments in other lawsuits challenging government action or inaction on climate change, such as Juliana, Leghari and Urgenda. While the legal systems of the various jurisdictions differ, as do the approaches employed by litigants, these cases share the aim of forcing governments to take more ambitious action to protect individuals from climate change harms. The following discussion examines KlimaSeniorinnen and other relevant cases in order to highlight the issues and arguments made by the senior women that might travel and inform future climate litigation.

\subsection{Justiciability of climate claims}

Justiciability is a universal issue that all litigants, including climate claimants, must address before filing a lawsuit. Many jurisdictions require plaintiffs to meet at least two basic requirements: first, a plaintiff must have standing to bring a claim before a court; and second, judicial action must not upset 'the principle of the separation or balance of powers'. ${ }^{158}$

\subsubsection{Standing}

In the development of the KlimaSeniorinnen request, counsel advised that senior women - as individuals and/or organized in an association - would have especially

153. See also Urgenda (n 1) [4.79].

154. FOEN, 'Climate Change: Questions and Answers: How Much $\mathrm{CO}_{2}$ does Switzerland Cause?' <https://www.bafu.admin.ch/bafu/en/home/topics/climate/climate-change-questionsand-answers.html>.

155. See Request (n 5) [42], where the argument is made that due to Articles 4.3 and 4.4 of the Paris Agreement, OECD 1990 countries such as Switzerland have to adopt a more stringent reduction target than other countries.

156. See eg Thomson v Minister for Climate Change Issues (2017) NZHC 733, 105-33 (hereinafter Thomson).

157. See eg Climate Justice Programme, 'Climate Justice: The International Momentum Towards Climate Litigation' (2016) <http://climatejustice.org.au/wp-content/uploads/2017/05/ Report-Climate-Justice-2016.pdf>.

158. Burger et al. (n 3) 27-8. 
strong grounds for standing to seek a ruling from authorities and later to sue, if necessary, for failures in climate protection under Swiss law. ${ }^{159}$ This advice was founded upon the occurrence of extreme heatwaves, a well-known and scientifically documented climate impact occurring in Switzerland, and on the fact that these heatwaves have been shown to have a disproportionate effect on older women. In its refusal to enter into the matter DETEC, however, denied standing - without discussing the alleged specific harm to older women. Instead, DETEC found the case to be an actio popularis by arguing that everyone, not just the applicants, would benefit from GHG emission reductions. ${ }^{160}$ This finding is at odds with other comparable cases, in which courts have taken a more progressive approach.

In Urgenda, for example, the foundation was granted standing because its purpose is 'to stimulate and accelerate the transition processes to a more sustainable society, beginning in the Netherlands', according to its by-laws. ${ }^{161}$ In Juliana, the court held that the youth plaintiffs had adequately established standing. ${ }^{162}$ It is of note this was despite the government's argument that the youth did not have standing because they were asserting a 'generalized grievance' and because climate change affects the entire planet and all people. The court stated that the alleged injuries, including 'harm to their personal, economic and aesthetic interests are concrete and particularized, not abstract or indefinite'. ${ }^{163}$ It was also determined that the plaintiffs adequately alleged a causal link between the defendants' conduct and the asserted injuries, and that the request for judicial relief would at least partially redress their injuries. ${ }^{164}$

KlimaSeniorinnen is a mission-driven organization similar to the Urgenda Foundation because the seniors formed a new association to promote the implementation of effective climate protections in the interest of its members. ${ }^{165}$ Due to the strict standing requirements in Switzerland, it was determined that senior women would have a good chance of succeeding because of the strong scientific evidence of older women being most at risk of harm from climate-induced heatwaves (see section 3.2 above). There is a close alignment between KlimaSeniorinnen and Juliana in terms of establishing standing. ${ }^{166}$ The senior women argue along the same lines as the standing test in Juliana, a case involving youth, that they should be granted standing on the basis of concrete and particularized harm to them, on the basis of an established causal link and on the basis that judicial relief would, likewise, partially redress their injuries: if the authorities were to increase the ambition in light of the Paris Agreement and fully implement all reasonable and practical mitigation measures, then Switzerland would be doing at least what is minimally required to reduce the risk of harm posed to senior women.

\subsubsection{Separation of powers}

Governments are likely to continue to challenge the authority of courts to rule on climate matters, arguing that such decisions are a matter for parliament, in order to avoid

159. Brunner and Bähr (n 50).

160. DETEC, ruling of 25 April 2017 (n 79) [2.1].

161. Urgenda (n 1) [2.2], [4.10].

162. Juliana (n 1) 18-28.

163. Ibid 20-21.

164. Ibid 26, 28.

165. Request (n 5) [12]-[13].

166. For the court's overview of the youth plaintiffs' injuries see eg Juliana (n 1) 19-20. 
accountability. As a human rights case, KlimaSeniorinnen calls for judicial review of whether rights have been violated. In order to avoid conflicting with the principle of separation of powers it was determined by the applicants that the best strategy was to challenge administrative actions by the competent administrative authorities that are reviewable by court, as explicitly allowed under the law, because it is not possible to challenge parliamentary acts under Article 190 of the Constitution. ${ }^{167}$ Accordingly, concerns about separation of powers were not raised by DETEC, although it did suggest that KlimaSeniorinnen should rather seek change by political means and address parliament with their concerns.

However, there is good reason to argue that such decisions fall firmly within the sphere of judicial competence in any case. In Urgenda, the applicants had to counter the argument that it is improper for judges to weigh in on climate policy because of the political consequences. ${ }^{168}$ The court's verdict clarified that Dutch law provides for a 'distribution of powers', and the court asserted its authority to provide legal protection and settle disputes concerning climate change. ${ }^{169}$ The Juliana opinion and order also echo that finding, stating that ' $[\mathrm{t}] \mathrm{h}$ ere is no need to step outside the core role of the judiciary to decide this case. At its heart, this lawsuit asks this court to determine whether defendants have violated plaintiffs' constitutional rights. That question is squarely within the purview of the judiciary'. ${ }^{170}$

Following in the footsteps of the Urgenda Foundation and the youth in the US, the Swiss senior women filed a request arguing that the authorities' acts and omissions have violated their constitutional and ECHR rights. Framed in this way, the case clearly raises legal questions for the court to consider. Given DETEC's decision not to contest this issue in its response, it appears that the authorities do not disagree, in any case, with such a position. As demonstrated by the positive developments in Juliana and Urgenda, courts are becoming more willing to assert authority over climate disputes because of the robust nature of climate science as summarized in IPCC reports, indisputable evidence of climate harm and greater understanding of the human rights obligations requiring climate protection and precautionary action. ${ }^{171}$

\subsection{Climate science}

Climate science provides an increasingly detailed factual basis for climate claims. The Swiss senior women argue that the findings of the IPCC reports establish the minimum emission reductions that Switzerland owes them. The IPCC AR4 and AR5 explain that industrialized countries such as Switzerland must reduce their emissions by 25 to 40 per cent below 1990 levels by 2020 and by 50 per cent by 2030 in order to 'likely' stabilize temperature increase at a maximum of $2^{\circ} \mathrm{C}$ (see section 3.1 above). The Swiss senior women argue that these emission reductions must be reached through domestic measures if this target is to be achieved, and that since the government has yet to adopt this magnitude of reductions in law, Switzerland is failing to act in accordance with the science it endorses.

167. Brunner and Bähr (n 50).

168. See eg Estrin (n 21) 12.

169. Urgenda (n 1) [4.95].

170. Juliana (n 1) 16.

171. Estrin (n 21) 12; Urgenda (n 1) [4.71]. 
The Urgenda verdict provided a guide for the Swiss senior women to use in interpreting the IPCC findings in order to define the targets and rate of GHG reductions that would prevent Switzerland from acting contrary to its human rights obligations. ${ }^{172}$ The plaintiffs in Juliana argue that the best available science requires an even lower threshold than the internationally agreed Paris targets. They assert that long-term warming must be limited to $1^{\circ} \mathrm{C}$ in order to prevent dangerous climate change, which requires reducing atmospheric $\mathrm{CO}_{2}$ concentrations to well below $350 \mathrm{ppm}$ by $2100 .{ }^{173}$

Building on Urgenda, the KlimaSeniorinnen request contains a roadmap of IPCC climate science for individuals and lawyers to consult in building future climate cases. The request provides technical explanations of climate change, impacts, carbon budgets and the correlating reductions in GHGs that states, industrialized ones in particular, must undertake in order to meet the 'well below $2^{\circ} \mathrm{C}$ ' target, aiming for $1.5^{\circ} \mathrm{C}$. The request therefore provides an example of how climate science, in particular IPCC reports, can help form the basis of arguments seeking to establish violations of constitutional and international human rights law. ${ }^{174}$

\subsection{Environmental principles and international law}

The Swiss senior women argue that the current and planned Swiss mitigation measures are inconsistent with environmental principles and agreements in international law, such as the precautionary principle, sustainable development and the Paris Agreement. While sustainable development may not be a directly applicable constitutional provision, it is a fundamental guiding principle necessary to ensure the existence of a liveable society for future generations. Although there is no legal obligation to avoid all conceivable risks, the precautionary principle requires Switzerland to at least comply with the global climate commitments (see section 4.2 above). Further, states must fulfil their commitments in international treaties in good faith. Arguably any industrialized country with climate laws and policies that are not in line with the Paris Agreement's minimum target ('well below $2^{\circ} \mathrm{C}^{\prime}$ with the aim of only $1.5^{\circ} \mathrm{C}$ temperature increase), such as Switzerland, is failing to act in accordance with binding international commitments.

The court in Urgenda explained that citizens cannot directly rely on international law to establish a breach by a government in a private claim, but that international obligations have a 'reflex effect' in national law. ${ }^{175}$ In Juliana, the court stated: 'There is no contradiction between promising other nations the United States will reduce $\mathrm{CO}_{2}$ emissions and a judicial order directing the United States to go beyond its international commitments to more aggressively reduce $\mathrm{CO}_{2}$ emissions'. ${ }^{176}$ The court explained that granting the youth plaintiffs' requested relief, government action in line with limiting warming to $1^{\circ} \mathrm{C}$ in order to comply with constitutional and public trust obligations would be 'fully consistent' with United States' international climate

172. Urgenda (n 1) [4.71].

173. Amended Complaint (n 22), 'Exhibit A' para 13; 'Exhibit 2: Assessing "Dangerous Climate Change": Required Reduction of Carbon Emissions to Protect Young People, Future Generations and Nature' (2013) <http://journals.plos.org/plosone/article?id=10.1371/journal. pone.0081648>; Our Children's Trust (n 23) iii.

174. An overview of the roadmap can be found in the Request's table of contents, in particular sections 4 and 5. Request (n 5) [146]-[149].

175. Urgenda (n 1) [4.43].

176. Juliana (n 1) 15. 
change commitments, even though it requires US action to go beyond these existing commitments. ${ }^{177}$ The KlimaSeniorinnen request does not directly rely on international agreements to hold the government accountable. Instead it argues that environmental principles and international law are material in making a determination of whether Switzerland's actions or inactions are contrary to domestic and ECHR human rights protections. This approach is in line with the courts' reasoning in Urgenda and Juliana and could be applied in other climate cases, particularly in countries that have committed to the Paris Agreement.

\subsection{Human rights}

\subsubsection{Climate change and human rights law}

It is widely acknowledged that climate change is a human rights crisis in the making; that 'international human rights law imposes affirmative legal obligations on all states to take the necessary steps in law, policy, institutions, and public budgets to protect human rights from such harms'; and that this includes preventing 'these harms by regulating environmental practices, to hold violators accountable, protect vulnerable communities, and ensure redress where harms are suffered'. ${ }^{178}$ In the next section we discuss how the reports and findings of international human rights bodies and experts ${ }^{179}$ support the claims made in the KlimaSeniorinnen case and the other climate-related human rights legal actions around the world.

\subsubsection{Obligation to protect human rights}

The KlimaSeniorinnen request argues that the Swiss government is in breach of its obligations to protect Swiss senior women's human rights. Switzerland is required to take positive and proportionate measures in accordance with its constitution, Swiss jurisprudence, the ECHR and ECtHR case law in order to protect the lives and health of senior women who are members of a group most vulnerable to climate change in the country. This means, as argued above, that Swiss authorities must take all necessary measures, including implementing and enforcing legislation and administrative and budgetary frameworks, to meet the Paris temperature goals. The obligation to protect the rights of those most vulnerable is non-negotiable. The Swiss authorities' weak climate targets and insufficient mitigation measures, which fail to align with the 'well below $2{ }^{\circ} \mathrm{C}$ ' $\operatorname{tar}$ get, let alone with the $1.5^{\circ} \mathrm{C}$ target, are not within the margin of appreciation. Further, while states are typically allowed a degree of latitude in implementing measures due to their proximity to the situation, in the instant case the Swiss authorities have discretion

177. Ibid.

178. ZR Al Hussein, 'Burning Down the House' (December 2015) <http://www.ohchr.org/EN/ NewsEvents/Pages/BurningDowntheHouse.aspx $>$. See also Office of the United Nations High Commissioner for Human Rights (OHCHR), 'Understanding Human Rights and Climate Change' <http://www.ohchr.org/Documents/Issues/ClimateChange/COP21.pdf>; Oslo Principles on Global Obligations to Reduce Climate Change (1 March 2015) <https://law.yale.edu/ system/files/area/center/schell/oslo_principles.pdf>.

179. The website of the OHCHR provides an overview of the resolutions, reports and other publications concerning human rights implications of climate change and legal obligations $<$ http://www.ohchr.org/EN/Issues/HRAndClimateChange/Pages/HRClimateChangeIndex. aspx $>$. 
only in the selection of measures to achieve the necessary emission reductions and in the decision to be more ambitious than the Paris Agreement.

There is growing awareness that government action or inaction on climate change that is not consistent with meeting global commitments interferes with the full enjoyment of human rights. ${ }^{180}$ The Juliana opinion and order recognized the possibility of a new right 'to a climate system capable of sustaining human life'. ${ }^{181}$ In Leghari, the court found that the government's failure to implement climate change policies 'offends the fundamental rights of the citizens which need to be safeguarded' ${ }^{182}$ The court in Urgenda considered that the state was acting negligently towards society in view of human rights obligations, including those found in the ECHR. ${ }^{183}$ As demonstrated by KlimaSeniorinnen and the other cases discussed, individuals vulnerable to climate change, such as the Swiss senior women, can claim that human rights obligations have been breached if governments fail to meet or strengthen the commitments made in the Paris Agreement.

\subsection{Mobilization of the law}

Social movements have often sought to influence legislative change, and when necessary, have turned to the courts to seek legal protection, legal reform and wider societal change. ${ }^{184}$ The now over one thousand senior women who are members of the KlimaSeniorinnen association are additionally involved in a spectrum of complementary political activities, including actively participating in legislative proceedings to secure more ambitious climate action post-2020. ${ }^{185}$ As a test case, KlimaSeniorinnen could help to refine current and future national climate legislation to ensure and enhance compliance with constitutional and ECHR protections, which is essential for safeguarding the lives and health of senior women as well as the greater population and future generations.

In deciding the best approach, future litigants will have to answer many of the same questions the Swiss senior women considered when they embarked on their legal journey. This includes: (1) whether current domestic climate laws, policies and measures are ambitious enough in light of the best available climate science and international climate commitments; (2) if not, whether national and international human rights protections provide a course of action by which individuals and groups, especially those most vulnerable to the impacts of climate change, can require the government to improve its climate laws, policies and measures; and (3) what procedural requirements individuals and groups must meet in order to sue the government for inadequate climate actions or

180. Report of the Special Rapporteur on the issue of human rights obligations relating to the enjoyment of a safe, clean, healthy and sustainable environment, A/HRC/31/52 (2016) paras [68]-[71], [76]-[77], [80], [88].

181. Juliana (n 1) 32.

182. Leghari (n 1) order 4 September 2015, 8.

183. Urgenda (n 1) [4.51]-[4.53].

184. L Vanhala, 'Legal Mobilization' (2011) <http://www.oxfordbibliographies.com/view/ document/obo-9780199756223/obo-9780199756223-0031.xml>. For more information on climate change and legal mobilization, see L Vanhala and C Hilson, 'Climate Change Litigation: Symposium Introduction' (2013) Law \& Policy 141-9.

185. KlimaSeniorinnen contributed to the consultation process on the post-2020 climate legislation, see <http://klimaseniorinnen.ch/wp-content/uploads/2016/11/Vernemlassungsantwort_ CO2Gesetz_klimaseniorinnen_20161129.pdf>. 
inactions. By answering these questions, we suggest, individuals can begin to determine whether they have a meritorious climate claim based on human rights grounds.

\section{CONCLUSION}

The KlimaSeniorinnen case holds five valuable lessons for future climate litigation. The lessons are transferable not only to cases brought in any country that is a party to the ECHR, but also, mutatis mutandis, to legal actions in other countries that invoke human rights protections - including the right to a safe and healthy environment ${ }^{186}-$ to achieve climate justice.

First, standing, or more generally, judicial recognition of climate-related harm to individuals, is often perceived to be a key barrier to climate litigation. ${ }^{187}$ Scientific evidence that older women are or will be specifically affected by climate change prompted the KlimaSeniorinnen case - and robust IPCC scientific evidence of the already occurring impacts and the documented risks that individuals face - is making it increasingly difficult to deny standing to individuals and groups threatened by climate change. Nonetheless, careful consideration of standing is still warranted in the development of climate cases. Subject, however, to relevant standing requirements and alleged violations, it is important that future litigants - both individuals and groups - base standing arguments on the latest peer-reviewed science to demonstrate how they fit the pertinent climate risk profiles.

Second, the typical government defence that climate matters should be handled by politicians and not by judges has been deployed in numerous contexts. A recent ruling by the High Court of New Zealand should put this argument to rest. The High Court reviewed decisions from other jurisdictions considering the issue of justiciability of government action or inaction on climate change and found that:

The various domestic courts have held they have a proper role to play in Government decision making on this topic, while emphasising that there are constitutional limits in how far that role may extend. The IPCC reports provide a factual basis on which decisions can be made. Remedies are fashioned to ensure appropriate action is taken while leaving the policy choices about the content of that action to the appropriate state body. ${ }^{188}$

If a Swiss court, or even the ECtHR, determines that the Swiss senior women's claim is admissible and requires judicial determination, then in the future, even more vulnerable individuals will be empowered to seek relief. Judiciaries have a proper and important role to play in resolving allegations of human rights violations, especially in climate cases such as KlimaSeniorinnen where it is alleged that government inaction puts fundamental rights at stake.

186. See eg F Magistro, Le droit à un environnement sain revisité - Etude de droit Suisse, international et comparé (Schulthess, Geneva 2017).

187. Back in 2007, the IACHR declined to rule on the Inuit Petition (n 11) because it did not enable the Commission 'to determine whether the alleged facts would tend to characterize a violation of [protected human] rights'. Discussed in J Knox, 'Linking Human Rights and Climate Change at the United Nations' (2009) 33 Harvard Environmental Law Review 477, 482. This determination contrasts with the recent decisions, such as in Juliana, Leghari and Urgenda, which recognize that there is strong scientific evidence of current and threatened climate-related harms to individuals.

188. Thomson (n 156) 133. 
Third, KlimaSeniorinnen provides future climate litigants with a roadmap on how to interpret and apply climate science, in particular IPCC reports, which provide factual grounds for climate claims and help individuals to determine the amount and rate of GHG reductions that their country should, at minimum, implement and enforce through domestic laws. Environmental principles and international law - most importantly the precautionary principle and the Paris Agreement - are material in determining whether a state's climate policy, measures and decisions will adequately prevent dangerous climate change.

Fourth, every country must act to mitigate climate change; no matter how small in size, how minor its emissions, even though 'the problem is a global one' and despite claims that 'one country's efforts alone cannot prevent harm to that country's people and their environment'. ${ }^{189}$ For state mitigation measures to comply with human rights obligations, UNFCCC's ultimate objective of preventing dangerous climate change must be met. ${ }^{190}$ This goal can be achieved only if all concerned parties do their share to meet international commitments.

Finally, strategic climate litigation such as KlimaSeniorinnen could result both in individual protection of human rights and in the improvement of climate policy at national and international level. At national level, such cases could lead to the implementation of the much-needed ambitious reduction of GHG emissions, while minimizing the costs and risks of delayed action. At international level, such cases could collectively help with the 'ratcheting up of ambition' of national determined contributions, ${ }^{191}$ thereby playing a critical role in closing the ambition gap between weak national climate laws and the long-term goals of the UNFCCC and the Paris Agreement. ${ }^{192}$

KlimaSeniorinnen, along with other climate cases, sends a clear signal to individuals vulnerable to climate change that there are strong legal grounds for human rights claims. It also puts governments on notice to expect more human rights litigation if national laws, policies and decisions with respect to climate and energy are in contravention of the Paris Agreement and of international law. ${ }^{193}$

189. Ibid. See also Urgenda (n 1) [4.79].

190. Article 2 UNFCCC.

191. S Yeo, 'Timeline: How Countries Plan to Raise their Ambition of their Climate Pledges' (January 2016) <https://www.carbonbrief.org/timeline-the-paris-agreements-ratchetmechanism>.

192. See eg UNEP, 'The Emissions Gap Report 2016' (2016) <http://www.unep.org/emissions gap/>.

193. The potential for successful climate litigation against governments and companies to 'lead to the decarbonisation of several sectors including energy, infrastructure, agriculture, transportation and finance', for example, was the subject of a paper published by Policy Horizons Canada, a federal department of the Canadian government <http://www.horizons.gc.ca/eng/content/what-ifgovernments-and-companies-are-challenged-courts-over-alleged-inaction-climate-change $>$. 